\title{
The Effect of Corporate Social Responsibility on Brand Performance with the Mediating Role of Corporate Reputation, Resource Commitment and Green Creativity
}

\author{
Ailar Ebrahimi Hesari, Elmira Shadiardehaei, Behzad Shahrabi*
}

\begin{abstract}
Following the strategic decisions of business managers in the community, issues have been raised that lead to changes in the community. One of these issues, which is becoming increasingly important, is consideration of corporate social responsibility. Therefore, the focus of this study was the effect of corporate social responsibility on brand performance with the mediating role of corporate reputation, resource commitment and green creativity. The research method was survey. The statistical population was employees of private banks, 507 of whom participated in the study. Structural equation modelling with SMARTPLS software was used to analyse the data. The results showed the effect of corporate social responsibility is positive and significant on resource commitment, green creativity, corporate reputation and brand performance. The effect of resource commitment, green creativity and corporate reputation is positive and significant on brand performance. Brand performance will be improved if the company supports employee higher education, encourages employees to develop their skills and abilities, implements flexible policies to provide work-life balance for employees, prioritizes employee needs and demands, has plans to reduce the negative effects of the company on the environment, and participates in activities aimed at protecting and improving the quality of the environment.
\end{abstract}

Keywords: brand performance; corporate reputation; corporate social responsibility; green creativity; resource commitment

\section{INTRODUCTION}

Following the strategic decisions of business managers in the community, issues have been raised that lead to changes in the community. One of these issues, which is becoming increasingly important, is consideration of corporate social responsibility in customer orientation literature [1]. In order to achieve their goals, businesses need a mechanism that can balance the resources of the company and stakeholders. As a result, the concept of corporate social responsibility is introduced [2, 3]. Based on social responsibility, companies take actions that improve the situation of society and refrain from actions that worsen the status of society, and ultimately have social accountability, attention to capacity to act and act on demands and expectations of society [4]. Corporate social responsibility is generally defined as activities that go beyond the mere economic interests of the company and includes actions to provide social benefits [5-7]. Carroll (1979), who has provided one of the most comprehensive definitions in this regard, considers corporate social responsibility as economic, legal, ethical and cautious expectations that society has of the company during a particular period of time [8]. Homburg et al. [9] claim that corporate social responsibility is a voluntary consideration of corporate concerns in relation to business and non-business processes. In the history of developed economies, corporate social responsibility has been mentioned as a key factor in achieving economic goals and wealth creation $[8,10]$. On the other hand, the prerequisite for success of the organization is its proper performance. Indicators such as profitability, survival, growth, achievement of goals and competitive capabilities can be considered as results of good performance. The performance of any company is the result of purposeful activities that are performed in order to earn economic profit. Well-performing companies usually know the channels of profit well and invest in those channels. Although the main goal of organizations is to increase efficiency and profit, in the age of information and globalization, they must respond appropriately to social expectations and ethical norms to achieve success, and best combine such expectations with economic goals of the organization to enable the achievement of higher goals. Studies that have examined the relationship between corporate social responsibility and corporate performance have shown that there is a positive and significant relationship between corporate social responsibility and corporate performance [11-16]. Therefore, it is assumed:

Hypothesis 1: Corporate social responsibility has a positive and significant effect on brand performance.

\subsection{Corporate Social Responsibility, Resource Commitment and Performance}

Resource commitment refers to the organization's committed effort for business strategies and has always been a key factor in the planning process for success [17]. Resource commitment can also be defined as an organization that uses resources to organize programs so that they result in better performance. When a company integrates environmental policies with its strategies and commits the resources needed to implement and execute them, it will see better performance compared to companies with fewer resources allocated for their green strategies [18]. Resource commitment has a strong impact on success of producers. To ensure the maintenance and continuity of regular export operations, it is essential to understand the attitudes of foreign buyers and conduct advanced marketing activities; in order to build such capacity, resource commitment is very important [19]. When a company is committed to resources, this tendency has a positive effect on the company's performance because it helps to develop the capabilities needed to operate efficiently. Lack of commitment to resources is one of the most important obstacles to performance. Therefore, an increase in resource commitment is needed to increase performance development. Companies 
with more resource commitment perform better. Numerous studies have emphasized the importance of green commitment as a key factor in building and maintaining long-term relationships between business partners. Studies that have examined the relationship between corporate social responsibility and commitment have shown that there is a positive and significant relationship between corporate social responsibility and commitment [20-24]. In addition, research has shown that there is a positive and significant relationship between resource commitment and performance [25-27]. Therefore, it is assumed:

Hypothesis 2: Corporate social responsibility has a positive and significant effect on resource commitment.

Hypothesis 3: Resource commitment has a positive and significant effect on brand performance.

\subsection{Corporate Social Responsibility, Green Creativity and Performance}

Environmental crises such as climate pollution, resource scarcity, declining biodiversity and global warming are the result of high urban growth rates, high population growth, large-scale land development and adverse effects on society, the environment and the economy. One of the issues that can play an important role in greening in organizations is green creativity [28]. Torrance (1995) considers creativity as a process that includes sensitivity to problems, shortcomings, bottlenecks, and inconsistencies. Sensitivity arises after diagnosing a problem or problems, followed by a search for solutions to problems and assumptions for this purpose. The assumptions are then tested and modified and the final results are obtained. Green creativity can help the company take effective environmental action. Green creativity refers to creation of new ideas about green goods, green services, green processes and green practices that are innovative, new, and useful $[29,30]$. With their creativity, companies can better respond to environmental changes and acquire new capabilities to achieve better performance. Creativity performance in the literature is one of the main factors in organizational performance that leads to organizational learning, renovation, improvement, learning from failures and adapting to a changing competitive environment [31]. Green creativity can be a new process to produce a product or service, a new management method or policy, or a new solution for business that reduces environmental risks, pollution and the negative effects of energy consumption (such as water, electricity, gas, oil, etc.) [32]. In addition, green creativity is considered as a new perspective, idea, product, service or process that seeks to reduce the negative environmental effects $[33,34]$.

Studies that have examined the relationship between corporate social responsibility and commitment have shown that there is a positive and significant relationship between corporate social responsibility and commitment [35-39]. In addition, research has shown that there is a positive and significant relationship between creativity and performance [40-44]. Therefore, it is assumed:

Hypothesis 4: Corporate social responsibility has a positive and significant effect on green creativity.
Hypothesis 5: Green creativity has a positive and significant effect on brand performance.

\subsection{Corporate Social Responsibility, Corporate Reputation and Performance}

Corporate reputation is the overall impact that reflects the perception of stakeholders about the organization's activities and examines the status of the product or service provided [45]. This reputation may be derived from various complementary pathways such as performance in use, advertising, and positive communication [46]. A good reputation prevents stakeholders from understanding negative information. Firms with higher reputation experiences are less likely to be exposed to adverse market reactions or disappointing earnings, and their reputation is less likely to be troubled as they shrink and downsize. In addition, good reputation attracts employees and customers [45]. Organizational researchers examine reputation as a social identity and portray it as an important and intangible resource that may effectively contribute to the organization's performance or even its survival [47]. Marketing authors examine reputation as brand equity [48] and relate it to corporate credibility [49]. Corporate reputation is the result of past activities of the company and may be seen as a mirror of history that can provide information about the company and quality of its products compared to competitors to its target groups [50].

Studies that have examined the relationship between corporate social responsibility and corporate reputation have shown that there is a positive and significant relationship between corporate social responsibility and corporate reputation [51-54]. In addition, research has shown that there is a positive and significant relationship between corporate reputation and performance [50, 54-56]. Therefore, it is assumed:

Hypothesis 6: Corporate social responsibility has a positive and significant effect on corporate reputation.

Hypothesis 7: Corporate reputation has a positive and significant effect on brand performance.

In short, it was once thought that companies were solely accountable to shareholders and employees, or that they had to offer the best product at a low price and high quality, regardless of the consequences. Some developments and changes in the world such as population growth and resource scarcity, environmental pollution, etc. have led to new approaches in the organization and its management; corporate social responsibility is one of these approaches. However, corporate social responsibility has become the dominant paradigm in corporate governance in the last decade, and large and reputable global companies have made social responsibility as part of their strategy. This concept is now strongly pursued in developed countries by stakeholders such as governments, civil societies, international organizations and scientific centers. That is why in the world of competition, corporate social responsibility has become a dominant paradigm. Therefore, the main objective of this study is to investigate the effect of corporate social responsibility on brand performance with the mediating role 
of corporate reputation, resource commitment and green creativity. According to the theoretical literature and the theoretical framework obtained from the background, the conceptual model of the study is drawn in Fig. 1.

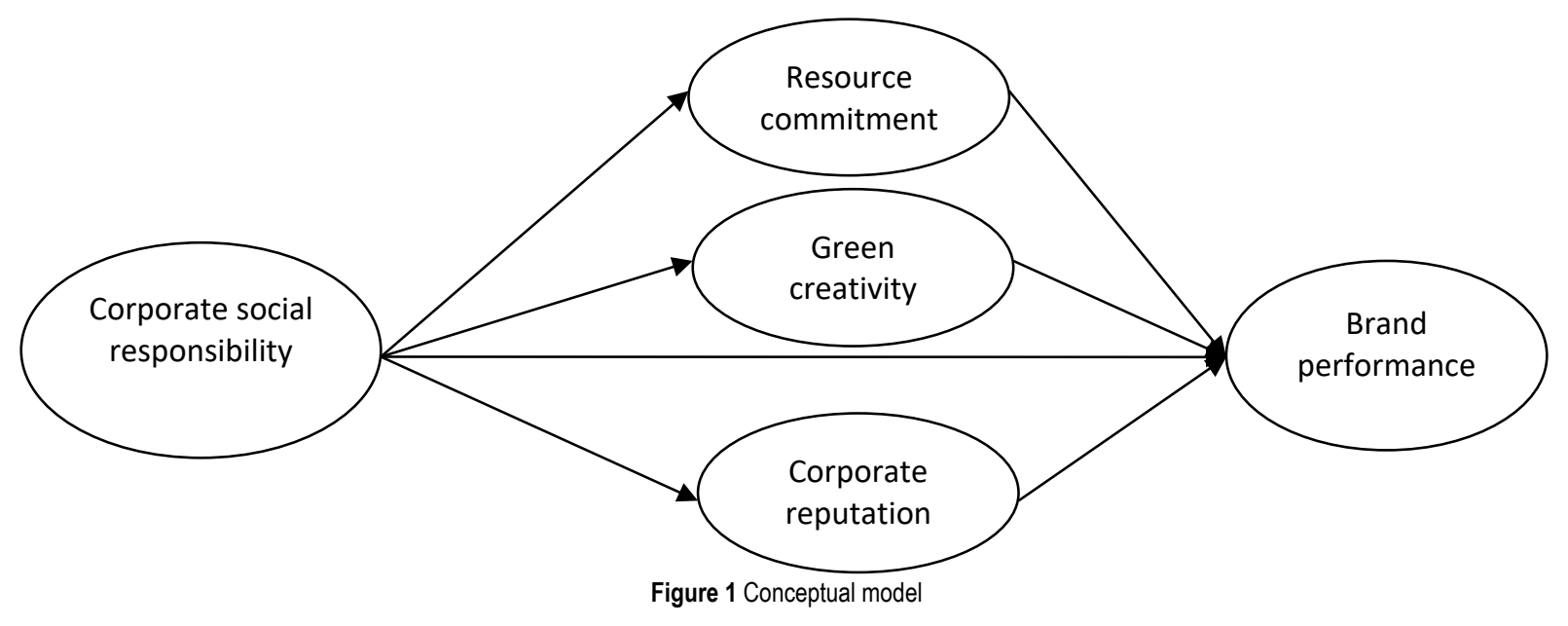

\section{MATERIALS AND METHODS}

The research method is descriptive-survey and the research design is correlation using structural equations with partial least squares; because this study examines the relationships between variables through a causal model.

\subsection{Statistical Population and Sample}

The statistical population was employees of private banks in Iran. For this purpose, 700 questionnaires were sent to employees of private banks in Iran, of which 507 (72.43 $\%)$ questionnaires were returned.

\subsection{Data Collection Instrument}

Corporate social responsibility (CSR): the questionnaire developed by Kim et al. [57] was used to measure corporate social responsibility. This questionnaire has 22 items that measure economic dimension (6 items), legal dimension (6 items), moral dimension (6 items) and humanitarian dimension (4 items). The items were weighed on a 5-point Likert scale from strongly disagree (1) to strongly agree (5).

Resource commitment (RC): the questionnaire developed by $\mathrm{Li}$ [58] was used to measure resource commitment. This questionnaire has 4 items. The items were weighed on a 5-point Likert scale from strongly disagree (1) to strongly agree (5).

Green creativity (GC): the questionnaire developed by Chen and Chang et al. [29] was used to measure green commitment. This questionnaire has 6 items. The items were weighed on a 5-point Likert scale from strongly disagree (1) to strongly agree (5).

Corporate Reputation (CR): the questionnaire developed by Park [53] and González-Rodríguez et al. [54] was used to measure corporate reputation. This questionnaire has 4 items. The items were weighed on a 5-point Likert scale from strongly disagree (1) to strongly agree (5).
Brand performance (BP): the questionnaire developed by Lei and Chaoyan [27] was used to measure brand performance. This questionnaire has 3 items. The items were weighed on a 5-point Likert scale from strongly disagree (1) to strongly agree (5).

\subsection{Data Analysis}

To analyse the data, coefficient of correlation and structural equation modelling with partial least squares (PLS) were used. SPSS and SMARTPLS3 software were used to analyse the data. PLS model is tested and interpreted in two steps: 1) measurement model and 2) structural model. The measurement model or confirmatory factor analysis, to answer questions about validity and reliability of the measurement, determines how latent variables or subconstructs are measured in the form of more observed variables. The structural model also shows the relationships between constructs (latent variables) and their explanatory power.

\section{RESULTS}

\subsection{Validity and Reliability of Instruments (Measurement Model Testing)}

The measurement model test includes checking the reliability (internal consistency) and validity (discriminant validity) of constructs and instruments [59]. To evaluate the reliability of constructs, Fornell and Larcker [60] propose three criteria, 1) reliability of each item, 2) composite reliability of each construct, and 3) average variance extracted. For reliability of each item, the factor load of 0.6 and more of each item in the confirmatory factor analysis indicates the suitability of each item of that construct. Moreover, the factor load of items should be significant at least at the level of 0.01 . Bootstrab test (with 700 subsamples) was used to calculate t-value to determine the significance of factor loads. Dillon-Goldstein coefficient $\left(\rho_{c}\right)$ was used to evaluate the composite reliability of each 
construct. Acceptable values of $\rho_{c}$ must be 0.7 or higher. The third criterion of reliability is average variance extracted [60]. Fornell and Larcker [60] recommend AVE values of 0.50 and above, which means that the construct explains about $50 \%$ or more of the variance of its markers. Tab. 1 presents the factor loads, $\rho_{c}$, and AVE of the variables. The values of these tables indicate sufficient and appropriate reliability of the constructs.

Table 1 Factor Loads, Composite Reliability and Average Variance Explained of Variables

\begin{tabular}{|c|c|c|c|c|c|}
\hline Variable & Item & Factor & $\rho_{c}$ & $\overline{C R}$ & $A V E$ \\
\hline \multirow{6}{*}{ Economic social responsibility } & 1 & 0.691 & \multirow{6}{*}{0.805} & \multirow{6}{*}{0.860} & \multirow{6}{*}{0.507} \\
\hline & 2 & 0.657 & & & \\
\hline & 3 & 0.765 & & & \\
\hline & 4 & 0.722 & & & \\
\hline & 5 & 0.671 & & & \\
\hline & 6 & 0.758 & & & \\
\hline \multirow{6}{*}{ Legal social responsibility } & 1 & 0.881 & \multirow{6}{*}{0.887} & \multirow{6}{*}{0.915} & \multirow{6}{*}{0.642} \\
\hline & 2 & 0.782 & & & \\
\hline & 3 & 0.698 & & & \\
\hline & 4 & 0.763 & & & \\
\hline & 5 & 0.829 & & & \\
\hline & 6 & 0.843 & & & \\
\hline \multirow{6}{*}{ Moral social responsibility } & 1 & 0.653 & \multirow{6}{*}{0.826} & \multirow{6}{*}{0.874} & \multirow{6}{*}{0.537} \\
\hline & 2 & 0.675 & & & \\
\hline & 3 & 0.779 & & & \\
\hline & 4 & 0.786 & & & \\
\hline & 5 & 0.795 & & & \\
\hline & 6 & 0.698 & & & \\
\hline \multirow{4}{*}{ Humanitarian social responsibility } & 1 & 0.824 & \multirow{4}{*}{0.827} & \multirow{4}{*}{0.885} & \multirow{4}{*}{0.658} \\
\hline & 2 & 0.835 & & & \\
\hline & 3 & 0.821 & & & \\
\hline & 4 & 0.764 & & & \\
\hline \multirow{4}{*}{ Resource commitment } & 1 & 0.878 & \multirow{4}{*}{0.907} & \multirow{4}{*}{0.934} & \multirow{4}{*}{0.782} \\
\hline & 2 & 0.918 & & & \\
\hline & 3 & 0.910 & & & \\
\hline & 4 & 0.830 & & & \\
\hline \multirow{6}{*}{ Green creativity } & 1 & 0.839 & \multirow{6}{*}{0.901} & \multirow{6}{*}{0.923} & \multirow{6}{*}{0.668} \\
\hline & 2 & 0.861 & & & \\
\hline & 3 & 0.828 & & & \\
\hline & 4 & 0.811 & & & \\
\hline & 5 & 0.833 & & & \\
\hline & 6 & 0.727 & & & \\
\hline \multirow{4}{*}{ Corporate reputation } & 1 & 0.664 & \multirow{4}{*}{0.798} & & \\
\hline & 2 & 0.803 & & 0867 & 0623 \\
\hline & 3 & 0.859 & & & 0.023 \\
\hline & 4 & 0.817 & & & \\
\hline & 1 & 0.815 & & & \\
\hline Brand performance & 2 & 0.857 & 0.793 & 0.879 & 0.707 \\
\hline & 3 & 0.849 & & & \\
\hline
\end{tabular}

The Fornell-Larcker (1981) index was used to evaluate validity or discriminant validity of the constructs. This index indicates that AVE of a construct should be greater than correlation of that construct with other constructs. This indicates that the correlation of that construct with its markers is greater than its correlation with other constructs. According to Tab. 2, all dimensions have the highest factor load on their own construct and minimum distance between the factor loads related to their own construct is more than 0.1 , suggesting that the constructs have good validity. Tab. 2 reports the results of correlation and Fornell-Larcker index, ie square root of AVE.
Table 2 Matrix of Correlation and Square Root of AVE of Variables

\begin{tabular}{|c|c|c|c|c|c|c|c|}
\hline Variable & Mean & SD & CSR & RC & GC & CR & BP \\
\hline CSR & 3.15 & 0.72 & 0.86 & & & & \\
\hline RC & 2.70 & 1.05 & $0.53^{* *}$ & 0.88 & & & \\
\hline GC & 3.03 & 0.92 & $0.54^{* *}$ & $0.63^{* *}$ & 0.82 & & \\
\hline CR & 3.04 & 0.88 & $0.55^{* *}$ & $0.59^{* *}$ & $0.52^{* *}$ & 0.79 & \\
\hline BP & 2.75 & 0.91 & $0.53^{* *}$ & $0.57^{* *}$ & $0.59^{* *}$ & $0.51^{* *}$ & 0.84 \\
\hline
\end{tabular}

According to Tab. 2, the root square of AVE of all variables is greater than their correlation with other variables. Therefore, the second criterion of discriminant validity is established. In addition, the numbers below the matrix diagonal were reported to examine the relationship between the variables. Obviously, the coefficient of correlation between all variables is positive and significant.

\subsection{Structural Model Testing}

To predict brand performance, the proposed conceptual model was examined through structural equation modeling method; according to the hypotheses, partial least squares method was used to estimate the model. Bootstrap method (with 700 sub-samples) was used to calculate t-values to determine the significance of path coefficients. Figure 2 shows the relationship between variables of the tested model. According to this figure, the effect of corporate social responsibility is positive and significant on resource commitment, green creativity, corporate reputation and brand performance. The effect of resource commitment, green creativity and corporate reputation is positive and significant on brand performance. Numbers in the circles are variance explained of variables.

Table 3 Path coefficients, T-values and variance explained

\begin{tabular}{|c|c|c|c|}
\hline Variable & $\beta$ & $t$-value & $\begin{array}{l}\text { Variance } \\
\text { ex. }\end{array}$ \\
\hline \multicolumn{4}{|l|}{ On brand performance vie: } \\
\hline Corporate reputation & $0.20 * *$ & 3.093 & \multirow{4}{*}{0.57} \\
\hline Green creativity & $0.26^{* *}$ & 4.152 & \\
\hline Resource commitment & $0.25 * *$ & 5.064 & \\
\hline Corporate social responsibility & $0.14 * *$ & 3.448 & \\
\hline \multicolumn{4}{|l|}{ On corporate reputation vie: } \\
\hline Corporate social responsibility & $0.56^{* *}$ & 15.343 & 0.32 \\
\hline \multicolumn{4}{|l|}{ On green creativity vie: } \\
\hline Corporate social responsibility & $0.54 * *$ & 13.617 & 0.29 \\
\hline \multicolumn{4}{|l|}{ On resource commitment vie: } \\
\hline Corporate social responsibility & $0.54 * *$ & 13.529 & 0.29 \\
\hline \multicolumn{4}{|c|}{ Mediating role of corporate reputation in relationship between: } \\
\hline $\begin{array}{l}\text { Corporate social responsibility and brand } \\
\text { performance }\end{array}$ & $0.11 * *$ & 3.032 & - \\
\hline \multicolumn{4}{|c|}{ Mediating role of green creativity in relationship between: } \\
\hline $\begin{array}{l}\text { Corporate social responsibility and brand } \\
\text { performance }\end{array}$ & $0.14 * *$ & 3.971 & - \\
\hline \multicolumn{4}{|c|}{ Mediating role of resource commitment in relationship between: } \\
\hline $\begin{array}{l}\text { Corporate social responsibility and brand } \\
\text { performance }\end{array}$ & $0.13 * *$ & 4.743 & - \\
\hline
\end{tabular}

Tab. 3 reports the estimate of path coefficients and variance explained of the variables. As shown in Tab. 3, 57 $\%$ of variance in brand performance, $32 \%$ of variance in corporate reputation, $29 \%$ of green creativity and $29 \%$ of 
resource commitment are explained by variables of the model.

The overall fit index in PLS is GOF index and it can be used to check validity or quality of the PLS model in general. This index examines the overall predictive ability of the model and whether the tested model is successful in predicting endogenous latent variables. In the present study, $G O F=0.59$ indicates the proper fit of the tested model. Values above 0.36 indicate good and acceptable quality of the model.

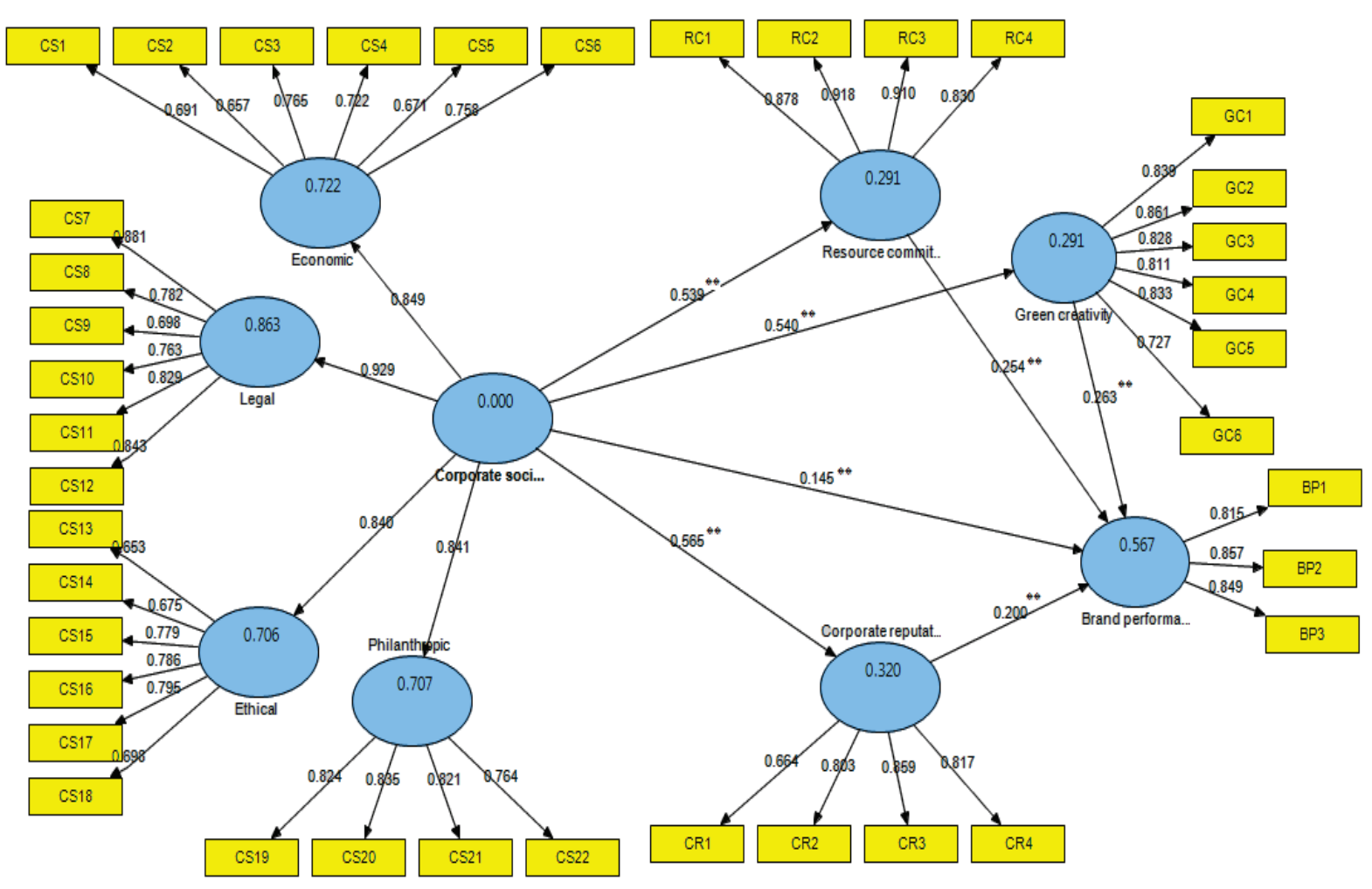

Figure 2 The tested model for predicting brand performance

\section{DISCUSSION AND CONCLUSION}

The objective of this study was to investigate the effect of corporate social responsibility on brand performance with the mediating role of corporate reputation, resource commitment and green creativity using the structural equation modeling. The results showed that the proposed model fits relatively well with data of this study and can explain $57 \%$ of the variance in brand performance, $32 \%$ of variance in corporate reputation, $29 \%$ of green creativity and $29 \%$ of resource commitment.

The results showed that corporate social responsibility has a positive and significant effect on brand performance. This finding is consistent with Selcuk and Kiymaz [11], Rahman and $\mathrm{Yu}$ [12], Lin et al. [13], Oware and Mallikarjunappa [14], Kong et al. [15] and Naseem et al. [16]. To explain this finding, it can be claimed that brand performance will be improved if the company supports employee higher education, encourages employees to develop their skills and abilities, implements flexible policies to provide work-life balance for employees, prioritizes employee needs and demands, provides accurate and comprehensive information to customers, cares about customer rights and satisfaction beyond legal requirements, has plans to reduce the negative effects of the company on the environment, and participates in activities aimed at protecting and improving the quality of the environment.

The results showed that corporate social responsibility has a positive and significant effect on resource commitment, green creativity and corporate reputation. This finding is consistent with Lee and Yoon [22], Chen et al. [23], Chaudhary and Akhouri [37], Ahmad et al. [35], Ko and Choi [39], Park [53], González-Rodríguez et al. [54] and Javed et al. [47]. To explain this finding, it can be claimed that resource commitment to social responsibility activities will increase, employees will have more green creativity and will provide more green ideas and thus corporate reputation will increase if the bank has methods for responding to customer complaints, uses customer satisfaction as one of the indicators of business performance, has been successful in maximizing profits, tries to reduce operating costs, has close monitoring of employee productivity, has long-term strategies, is aware of environmental laws, provides all services with legal standards, considers a duty to fulfill the obligations stated in the contracts and agreements, tries to enforce the rules, tries to comply with all rules related to employment and employee benefits, follows professional standards, monitors the negative effect of activities on the community, is recognized as trustworthy, considers justice to colleagues and clients as one of the main parts of the employee evaluation process, has reliable ways for 
employees to report any behavior at work, improves its business-related humanitarian activities, participates in charitable activities, contributes to improvement of society and strives to fulfill its social responsibilities.

The results showed that resource commitment has a positive and significant effect on brand performance. This finding is consistent with Zhang and Walton [25], Wu [26] and Lei and Chaoyan [27]. This finding suggests that brand performance will be improved if the company's managers allocate financial resources in a timely manner, consider the necessary human resources for economic activities, the company's managers have good management skills and the company's managers are committed to their financial obligations.

The results showed that green creativity has a positive and significant effect on brand performance. This finding is consistent with $\mathrm{Wu}$ [26], Chen et al. [23], Boso et al. [41], Aeknarajindawat and Jermsittiparsert [40] and Ferreira et al. [43]. To explain this finding, it can be claimed that brand performance will be improved if company employees propose new ways to achieve environmental goals, suggest new green ideas to improve environmental performance, promote new green ideas to others, develop good plans for implementing green ideas, and come up with creative solutions to environmental issues.

The results showed that corporate reputation has a positive and significant effect on brand performance. This finding is consistent with Gonzalez Sanchez and Morales de Vega [56], Kowalczyk and Kucharska [50], GonzálezRodríguez et al. [54] and Javed et al. [47]. To explain this finding, it can be claimed that corporate performance will be improved if the company is known and reputable, the company has chosen a good name for itself, the company has a good reputation and the company is one of the most important in its industry. In addition, a company with a wellknown brand has more power in the competition arena and makes the consumer loyal to the product, and as a result, the corporate performance improves.

Overall, the results showed that corporate reputation, resource commitment and green creativity mediate the effect of corporate social responsibility on brand performance. Therefore, corporate social responsibility leads to increased corporate reputation, resource commitment and green creativity and thus improves brand performance.

\section{IMPLICATIONS}

It is recommended that bank employees be trained in the skills needed to perform and achieve social responsibilities and to increase environmental awareness, provide regular training on social issues to employees, provide opportunities for employees to engage in social issues, and provide resources to educate employees on social issues. Banks are known as a very professional and successful company by providing quality services to customers and thus gain reputation for the company. It is recommended to allocate financial resources to social issues in a timely manner, consider the necessary human resources for social activities, company managers have good management skills, and company managers adhere to their financial obligations, and the company has sufficient financial resources for investing in innovative environmental methods. Companies should support new green ideas by employees, develop appropriate plans for implementing green ideas, and encourage employees to come up with creative solutions to environmental and social problems.

\section{LIMITATIONS}

In this study, only a sample of employees of private banks was examined; therefore, generalizations are limited. Moreover, the findings are based on self-report data. It is suggested that qualitative and mixed research methods be used in future studies.

\section{REFERENCES}

[1] Carroll, A. B. \& Brown, J. A. (2018). Corporate social responsibility: A review of current concepts, research, and issues. In Corporate social responsibility. Emerald Publishing Limited. https://doi.org/10.1108/S2514-175920180000002002

[2] Bieri, F. (2012). Corporate social responsibility. The WileyBlackwell Encyclopedia of Globalization.

[3] Crane, A., Matten, D., \& Spence, L. (Eds.). (2019). Corporate social responsibility: Readings and cases in a global context. Routledge. https://doi.org/10.4324/9780429294273

[4] Banerjee, S. \& Wathieu, L. (2017). Corporate social responsibility and product quality: Complements or substitutes? International Journal of Research in Marketing, 34(3), 734-745. https://doi.org/10.1016/j.jiresmar.2017.06.006

[5] Freeman, I. \& Hasnaoui, A. (2011). The meaning of corporate social responsibility: The vision of four nations. Journal of business Ethics, 100(3), 419-443. https://doi.org/10.1007/s10551-010-0688-6

[6] Bai, X. \& Chang, J. (2015). Corporate social responsibility and firm performance: The mediating role of marketing competence and the moderating role of market environment. Asia Pacific Journal of Management, 32(2), 505-530. https://doi.org/10.1007/s10490-015-9409-0

[7] Ferrell, O. C., Harrison, D. E., Ferrell, L., \& Hair, J. F. (2019). Business ethics, corporate social responsibility, and brand attitudes: An exploratory study. Journal of Business Research, 95, 491-501. https://doi.org/10.1016/j.jbusres.2018.07.039

[8] Saeidi, S. P., Sofian, S., Saeidi, P., Saeidi, S. P., \& Saaeidi, S. A. (2015). How does corporate social responsibility contribute to firm financial performance? The mediating role of competitive advantage, reputation, and customer satisfaction. Journal of business research, 68(2), 341-350. https://doi.org/10.1016/j.jbusres.2014.06.024

[9] Homburg, C., Stierl, M., \& Bornemann, T. (2013). Corporate social responsibility in business-to-business markets: How organizational customers account for supplier corporate social responsibility engagement. Journal of Marketing, 77(6), 5472. https://doi.org/10.1509/jm.12.0089

[10] Garriga, E. \& Melé, D. (2004). Corporate social responsibility theories: Mapping the territory. Journal of business ethics, 53(1-2), 51-71. https://doi.org/10.1023/B:BUSI.0000039399.90587.34 
[11] Selcuk, E. A. \& Kiymaz, H. (2017). Corporate social responsibility and firm performance: Evidence from an emerging market. Accounting and Finance Research, 6(4), 42. https://doi.org/10.5430/afr.v6n4p42

[12] Rahman, J. M. \& Yu, F. (2019). The relationship between corporate social responsibility and firm performance in China. Risk Governance \& Control: Financial Markets \& Institutions. https://doi.org/10.22495/rgcv9i4p4

[13] Lin, W. L., Ho, J. A., Ng, S. I., \& Lee, C. (2019). Does corporate social responsibility lead to improved firm performance? The hidden role of financial slack. Social Responsibility Journal. https://doi.org/10.1108/SRJ-10-2018-0259

[14] Oware, K. M. \& Mallikarjunappa, T. (2019). Corporate social responsibility investment, third-party assurance and firm performance in India. South Asian Journal of Business Studies. https://doi.org/10.1108/SAJBS-08-2018-0091

[15] Kong, Y., Antwi-Adjei, A., \& Bawuah, J. (2020). A systematic review of the business case for corporate social responsibility and firm performance. Corporate Social Responsibility and Environmental Management, 27(2), 444-454. https://doi.org/10.1002/csr.1838

[16] Naseem, T., Shahzad, F., Asim, G. A., Rehman, I. U., \& Nawaz, F. (2020). Corporate social responsibility engagement and firm performance in Asia Pacific: The role of enterprise risk management. Corporate Social Responsibility and Environmental Management, 27(2), 501-513. https://doi.org/10.1002/csr.1815

[17] Lai, F., Li, D., Wang, Q., \& Zhao, X. (2008). The information technology capability of third-party logistics providers: a resource-based view and empirical evidence from China. Journal of supply chain management, 44(3), 22-38. https://doi.org/10.1111/j.1745-493X.2008.00064.x

[18] Mittal, S. \& Dhar, R. L. (2015). Transformational leadership and employee creativity. Management Decision. https://doi.org/10.1108/MD-07-2014-0464

[19] Chugan, P. K. \& Singh, S. (2014). Taxonomy for firm-level determinants of export performance. Universal Journal of Industrial and Business Management, 2(1), 6-12.

[20] Mory, L., Wirtz, B. W., \& Göttel, V. (2016). Factors of internal corporate social responsibility and the effect on organizational commitment. The International Journal of Human Resource Management, 27(13), 1393-1425. https://doi.org/10.1080/09585192.2015.1072103

[21] Prutina, Ž. (2016). The effect of corporate social responsibility on organizational commitment. Management: Journal of Contemporary Management, issues 21(Special issue), 227248.

[22] Lee, S. \& Yoon, J. (2018). Does the authenticity of corporate social responsibility affect employee commitment? Social Behavior and Personality: an international journal, 46(4), 617-632. https://doi.org/10.2224/sbp.6475

[23] Chen, H. L., Hu, Y. C., Lee, M. Y., \& Yen, G. F. (2020). Importance of Employee Care in Corporate Social Responsibility: An AHP-Based Study from the Perspective of Corporate Commitment. Sustainability, 12(15), 5885. https://doi.org/10.3390/su12155885

[24] Afsar, B. \& Umrani, W. A. (2020). Corporate social responsibility and pro-environmental behavior at workplace: The role of moral reflectiveness, coworker advocacy, and environmental commitment. Corporate Social Responsibility and Environmental Management, 27(1), 109-125. https://doi.org/10.1002/csr.1777

[25] Zhang, J. A. \& Walton, S. (2017). Eco-innovation and business performance: the moderating effects of environmental orientation and resource commitment in greenoriented SME s. R\&D Management, 47(5), E26-E39. https://doi.org/10.1111/radm.12241

[26] Wu, G. C. (2017). Environmental innovation approaches and business performance: effects of environmental regulations and resource commitment. Innovation, 19(4), 407-427. https://doi.org/10.1080/14479338.2017.1358102

[27] Lei, H. \& Chaoyan, W. (2017). The Impact of B2B Brand Orientation on Brand Performance: The Role of Suppliers' Resource Commitment. Management Review, (9), 16.

[28] Zameer, H., Wang, Y., \& Yasmeen, H. (2020). Reinforcing green competitive advantage through green production, creativity and green brand image: implications for cleaner production in China. Journal of Cleaner Production, 247, 119119. https://doi.org/10.1016/j.jclepro.2019.119119

[29] Chen, Y. S. \& Chang, C. H. (2013). The determinants of green product development performance: Green dynamic capabilities, green transformational leadership, and green creativity. Journal of business ethics, 116(1), 107-119. https://doi.org/10.1007/s10551-012-1452-x

[30] Song, W., \& Yu, H. (2018). Green innovation strategy and green innovation: The roles of green creativity and green organizational identity. Corporate Social Responsibility and Environmental Management, 25(2), 135-150. https://doi.org/10.1002/csr.1445

[31] Gunday, G., Ulusoy, G., Kilic, K., \& Alpkan, L. (2011). Effects of innovation types on firm performance. International Journal of production economics, 133(2), 662-676. https://doi.org/10.1016/j.ijpe.2011.05.014

[32] Van den Bergh, J. C., Truffer, B., \& Kallis, G. (2011). Environmental innovation and societal transitions: Introduction and overview. Environmental innovation and societal transitions, 1(1), 1-23. https://doi.org/10.1016/j.eist.2011.04.010

[33] Dangelico, R. M., Pujari, D., \& Pontrandolfo, P. (2017). Green product innovation in manufacturing firms: A sustainabilityoriented dynamic capability perspective. Business strategy and the Environment, 26(4), 490-506. https://doi.org/10.1002/bse.1932

[34] Seman, N. A. A., Zakuan, N., Jusoh, A., Arif, M. S. M., \& Saman, M. Z. M. (2012). The relationship of green supply chain management and green innovation concept. ProcediaSocial and Behavioral Sciences, 57, 453-457. https://doi.org/10.1016/j.sbspro.2012.09.1211

[35] Ahmad, I., Donia, M. B., \& Shahzad, K. (2019). Impact of corporate social responsibility attributions on employees' creative performance: The mediating role of psychological safety. Ethics \& Behavior, 29(6), 490-509. https://doi.org/10.1080/10508422.2018.1501566

[36] Chaudhary, R. \& Akhouri, A. (2018). Linking corporate social responsibility attributions and creativity: Modeling work engagement as a mediator. Journal of cleaner production, 190 , 809-821. https://doi.org/10.1016/j.jclepro.2018.04.187

[37] Chaudhary, R. \& Akhouri, A. (2019). CSR perceptions and employee creativity: Examining serial mediation effects of meaningfulness and work engagement. Social Responsibility Journal. https://doi.org/10.1108/SRJ-01-2018-0018

[38] Hur, W. M., Moon, T. W., \& Ko, S. H. (2018). How employees' perceptions of CSR increase employee creativity: Mediating mechanisms of compassion at work and intrinsic motivation. Journal of Business Ethics, 153(3), 629-644. https://doi.org/10.1007/s10551-016-3321-5

[39] Ko, S. H. \& Choi, Y. (2020). The Effect of CSR Perception on Creativity: The Mediating Effect of Compassion and the 
Moderating Effect of CSR Authenticity. Journal of Digital Convergence, 18(3), 59-70.

[40] Aeknarajindawat, N. \& Jermsittiparsert, K. (2019). The mediating role of green creativity in the relationship between proactive green innovation, reactive green innovation and the performance of Green product development: A case of Thai sports manufacturing firms. https://doi.org/10.14198/jhse.2019.14.Proc5.45

[41] Boso, N., Donbesuur, F., Bendega, T., Annan, J., \& Adeola, O. (2017). Does organizational creativity always drive market performance? Psychology \& Marketing, 34(11), 1004-1015. https://doi.org/10.1002/mar.21039

[42] Chen, Y. S., Chang, T. W., Lin, C. Y., Lai, P. Y., \& Wang, K. H. (2016). The influence of proactive green innovation and reactive green innovation on green product development performance: The mediation role of green creativity. Sustainability, 8(10), 966. https://doi.org/10.3390/su8100966

[43] Ferreira, J., Coelho, A., \& Moutinho, L. (2020). Dynamic capabilities, creativity and innovation capability and their impact on competitive advantage and firm performance: The moderating role of entrepreneurial orientation. Technovation, 92, 102061. https://doi.org/10.1016/j.technovation.2018.11.004

[44] Wu, C. (2016). Entrepreneurial leadership, organisational creativity, and firm performance in Chinese SMEs context (Doctoral dissertation, University of Nottingham).

[45] Lai, C. S., Chiu, C. J., Yang, C. F., \& Pai, D. C. (2010). The effects of corporate social responsibility on brand performance: The mediating effect of industrial brand equity and corporate reputation. Journal of business ethics, 95(3), 457-469. https://doi.org/10.1007/s10551-010-0433-1

[46] Palmeira, M. (2014). The interplay of products from the same product line: the role of brand reputation. European Journal of Marketing. https://doi.org/10.1108/EJM-03-2013-0159

[47] Javed, M., Rashid, M. A., Hussain, G., \& Ali, H. Y. (2020). The effects of corporate social responsibility on corporate reputation and firm financial performance: Moderating role of responsible leadership. Corporate Social Responsibility and Environmental Management, 27(3), 1395-1409. https://doi.org/10.1002/csr.1892

[48] Liu, M. \& Lu, W. (2019). Corporate social responsibility, firm performance, and firm risk: the role of firm reputation. AsiaPacific Journal of Accounting \& Economics, 1-21. https://doi.org/10.1080/16081625.2019.1601022

[49] Gangi, F., Daniele, L. M., \& Varrone, N. (2020). How do corporate environmental policy and corporate reputation affect risk-adjusted financial performance? Business Strategy and the Environment. https://doi.org/10.1002/bse.2482

[50] Kowalczyk, R. \& Kucharska, W. (2020). Corporate social responsibility practices incomes and outcomes: Stakeholders' pressure, culture, employee commitment, corporate reputation, and brand performance. A Polish-German crosscountry study. Corporate Social Responsibility and Environmental Management, 27(2), 595-615. https://doi.org/10.1002/csr.1823

[51] Famiyeh, S., Kwarteng, A., \& Dadzie, S. A. (2016). Corporate social responsibility and reputation: some empirical perspectives. Journal of Global Responsibility. https://doi.org/10.1108/JGR-04-2016-0009

[52] Lu, J., Ren, L., He, Y., Lin, W., \& Streimikis, J. (2019). Linking corporate social responsibility with reputation and brand of the firm. Amfiteatru Economic, 21(51), 442-460. https://doi.org/10.24818/EA/2019/51/422

[53] Park, E. (2019). Corporate social responsibility as a determinant of corporate reputation in the airline industry. Journal of retailing and consumer services, 47, 215-221. https://doi.org/10.1016/j.jretconser.2018.11.013

[54] González-Rodríguez, M. R., Martín-Samper, R. C., Köseoglu, M. A., \& Okumus, F. (2019). Hotels' corporate social responsibility practices, organizational culture, firm reputation, and performance. Journal of Sustainable Tourism, 27(3), 398-419. https://doi.org/10.1080/09669582.2019.1585441

[55] Weng, P. S. \& Chen, W. Y. (2017). Doing good or choosing well? Corporate reputation, CEO reputation, and corporate financial performance. The North American Journal of Economics and Finance, 39, 223-240. https://doi.org/10.1016/j.najef.2016.10.008

[56] Gonzalez Sanchez, M. \& Morales de Vega, M. E. (2018). Corporate reputation and firms' performance: Evidence from Spain. Corporate Social Responsibility and Environmental Management, 25(6), 1231-1245. https://doi.org/10.1002/csr.1634

[57] Kim, K. H., Kim, M., \& Qian, C. (2018). Effects of corporate social responsibility on corporate financial performance: A competitive-action perspective. Journal of Management, 44(3), 1097-1118. https://doi.org/10.1177/0149206315602530

[58] Li, Y. (2014). Environmental innovation practices and performance: moderating effect of resource commitment. Journal of Cleaner Production, 66, 450-458. https://doi.org/10.1016/j.jclepro.2013.11.044

[59] Mortezaei, A., Sangari, M. S., Nazari-Shirkouhi, S., \& Razmi, J. (2018). The Impact of Business Intelligence (BI) Competence on Customer Relationship Management (CRM) Process: An Empirical Investigation of the Banking Industry. Journal of Information Technology Management, 10(1), 209234.

[60] Fornell, C. \& Larcker, D. F. (1981). Structural Equation Models with Unobservable Variables and Measurement Error: Algebra and Statistics. Journal of Marketing Research, 18(3), 382-388. https://doi.org/10.1177/002224378101800313

\section{Authors' contacts:}

Ailar Ebrahimi Hesari

Department of Management,

Aliabad Katoul Branch,

Islamic Azad University,

Aliabad Katoul, Iran

E-mail: ailar.ebrahimi@gmail.com

\section{Elmira Shadiardehae}

Department of Management,

Aliabad Katoul Branch,

Islamic Azad University,

Aliabad Katoul, Iran

E-mail: elmira_shadi99@yahoo.com

Behzad Shahrabi

Department of Management,

Aliabad Katoul Branch,

Islamic Azad University,

Aliabad Katoul, Iran

E-mail: b.shahrabi@gmail.com 